\title{
進行喉頭癌（病期III，IV）症例の治療成績とその検討
}

$\begin{array}{ll}\text { 藤 沢 } & \text { 勉, 仲宗根 康二, 越 井 健 司 } \\ \text { 平林 秀 樹, 宇野 浩 平, 大垣 治幸 } \\ \text { 生野 } \\ \text { 登, 平林 敬之, 日野原 正 }\end{array}$

\section{Clinical Evaluation and Analysis of Treatments for Advanced Laryngeal Carcinoma (Stage III, Stage IV)}

Tsutomu Fujisawa, M.D., Yasuji Nakasone, M.D., Kenji Koshii, M.D., Hideki Hirabayashi, M.D., Kohei Uno, M.D., Haruyuki Ohgaki, M.D., Noboru Shono, M.D., Keishi Hirabayashi, M.D., and Tadashi Hinohara, M.D.

Department of Bronchoesophagology, Dokkyo University School of Medicine, Tochigi

We reported aggressive treatment for patients with Stage III and IV laryngeal carcinomas based on our study of the records of 89 consecutive patients (previously untreated) who presented stage III and IV carcinomas of the larynx in the period 1975-89. Of these, 53 were stage III patients and 36 were stage IV, and the histological diagnosis in every case was squamous cell carcinoma. The average age of the patients was 66.2 years, and the male-female ratio was 9 to 1 .

In the advanced laryngeal carcinoma, the incidence in the cases of supraglottic carcinoma $(47 / 89,52.8 \%)$ was higher than in the cases of glottic carcinoma $(37 / 89,41.6 \%)$. Thirty-one of the 47 cases of supraglottic carcinoma $(66.0 \%)$ had metastasis to the jugular lymph nodes.

The 5 -year cumulative survival rate, viewed by stages, was $63.8 \%$ for stage III glottic carcinoma, $74.4 \%$ for stage IV glottic carcinoma, $60.9 \%$ for stage III supraglottic carcinoma and $40.0 \%$ for stage IV supraglottic carcinoma.

Initial examinations revealed metastasis to the jugular lymph nodes in 41 cases. Prognosis was poor, with the 5 -year cumulative survival rate for these cases (47.5\%) lower than that for the 48 cases without metastasis $(66.3 \%)$.

Twenty of the 89 cases of advanced laryngeal carcinoma were classified as poorly differentiated squamous cell carcinoma, and the 5-year cumulative survival rate for these $(33.1 \%)$ was definitely lower than for that the well differentiated types $(69.4 \% ; P<0.05)$.

We conclude that wide resection with complete neck dissection, including irradiation and chemotherapy, is indicated for stage III and IV laryngeal carcinomas-particularly in patients who have supraglottic stage IV tumors with poorly differentiated squamous cell carcinoma. Adjuvant and neo-adjuvant chemotherapy should be administered to prevent lung metastasis, which is the most recurrent form of cancer.

Key words : advanced laryngeal carcinoma (stage III, IV), prognosis

獨協医科大学気管食道科学教室

別刷請求： T321-02 栃木県下都賀郡壬生町北小林880 獨協医科大学気管食道科学教室 藤沢 勉 投稿受付：1993年 3 月 9 日 


\section{I . はじめに}

喉頭癌は耳鼻咽喉科頭頸部領域において発症 頻度の高い悪性腫瘍であるが，その予後は比較 的良いとされている。早期症例は放射線感受性 の高いものが多く, 放射線単独で根治可能なも のがほとんどである。しかし，進行喉頭癌（病 期III，IV) 症例は，放射線のみでは限界があり， 手術を主体とした集学的治療がなされてい $る^{1 \sim 4)}$ 。

進行喉頭癌の治療方針は，手術不能・拒否例 を除いて手術を主体とした集学的治療を原則と しているが，いまだ満足すべき成績が得られて いない。

今回, 当科における進行喉頭癌症例について, 受診までの経過, 発癌部位, 進展範囲, 病理組 織学的分化度, 治療内容, 治療成績, 予後因子

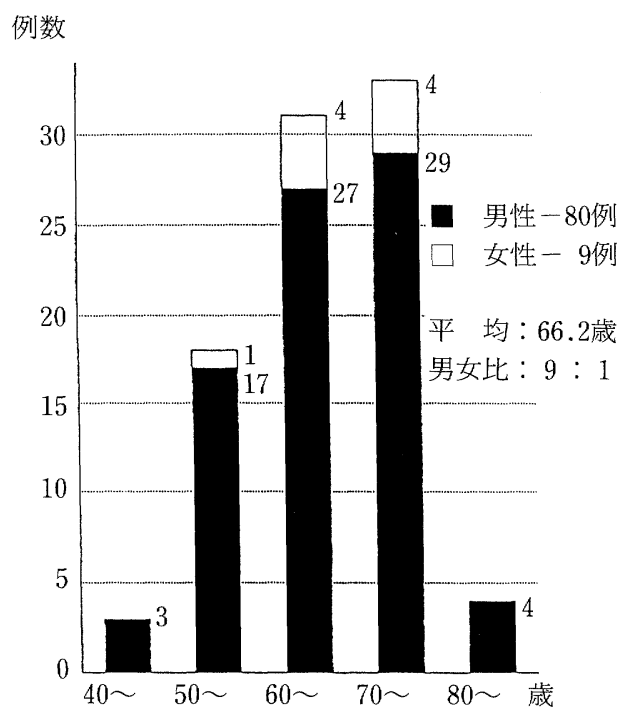

図 1 病期III, IVO性・年歯命分布

表 1 病期III，IVにおける部位別および病期別頻度

\begin{tabular}{|c|c|c|c|c|}
\hline & 声門 & 声門上 & 声門下 & 計 \\
\hline 病期 III & 24 & 27 & 2 & 53例 \\
\hline IV & 13 & 20 & 3 & 36 \\
\hline 計 & 37 & 47 & 5 & 89 \\
\hline
\end{tabular}

などを調査し，成績向上のためにはいかにすべ きかについて検討を加えた。

\section{II. 対 象}

1975年11月から1989年10月までの14年間に， 当科で治療した進行喉頭癌の新鮮例は89例（III 期53例，IV期36例）であった。

性別は, 男性 80 例, 女性 9 例, 男女比 $9: 1$ であり, 年齢は 43 歳〜 85歳, 平均 66.2 歳であっ た（図 1)。

発生部位は，声門37例 (41.6\%), 声門上47例 (52.8\%)，声門下 5 例(5.6\%)であった(表 1)。

フォローアップ期間は 4 ～153カ月, 平均 49.3 カ月であった。病期分類は1978年 UICC 分類を 使用し, 生存率の算出は Kaplan-Meier 法を使 用した。なお扁平上皮癌以外の悪性腫場は除外 した。

\section{III. 結 果}

\section{TNM 分類}

初診時における病期III・IV症例の頸部リンパ 節転移の頻度は，声門癌 $8 / 37$ (21.6\%), 声門 上癌 $31 / 47(66.0 \%)$, 声門下癌 $2 / 5(40.0 \%)$ であり声門上癌において高頻度に認められた （表 2 ）。なお，初診時に遠隔転移を有した症例 は声門上癌 T4N3 と T3N1の 2 例であった。

\section{2. 主訴および受診までの期間}

病期III・IVにおける受診時の主訴については 延べ数で部位別にみると，声門癌で嗄声が 37 例 中34例 $(91.9 \%)$ と圧倒的に多かった。また, 声門上癌の中では嗄声が47例中 28 例 $(59.6 \%)$ と多かったが, 嗄声以外でも咽頭痛, 頸部腫瘤, 咳嗽などが多く認められた（表 3 )。

症状出現から受診までの平均月数はIII，IV期 の声門癌で8.9力月, 声門上癌で 6.8 力であり 大差はなかった（表 4 ）。

\section{3 . 病期III, IV 症例に対する治療内容}

病期III, IV 症例 89 例中, 根治を目的とした治 療が可能であった症例は79例，その他手術拒否 5 例, 手術不能 5 例であった。根治治療の内容 を表 5 に示した。放射線著効例が 4 例あり，4 例とも $\mathrm{N} 0$ 症例であった。

手術と放射線併用群39例と三者併用群 8 例を 合わせた47例中，術前照射は38例，術後照射は 
10例であった。術前照射38例中，根治照射 （60～65 Gy）後手術は12例であった。

手術を施行した75例中, 喉頭摘出術が64例 (う ち頸部郭清45例), 喉頭部分切除術は 8 例 (うち 頸部郭清 6 例), 根治照射後の頸部郭清のみが 3 例であった（表 6 )。

すなわち, 喉頭部分切除 8 例, 根治照射十頸 部郭清 3 例, 根治照射のみ 4 例を加えた 15 例(19 \%）は喉頭機能を保存できた。

表 2 病期III，IVに扔ける部位別TNM分類

\begin{tabular}{|c|c|c|c|c|c|}
\hline & \multicolumn{4}{|c|}{ 声門癌 } & \multirow{2}{*}{ 計 } \\
\hline & N0 & N1 & $\mathrm{N} 2$ & N3 & \\
\hline $\mathrm{T} 1$ & & 0 & 0 & 0 & 0 \\
\hline $\mathrm{T} 2$ & & 1 & 0 & 0 & 1 \\
\hline T3 & 22 & 1 & 3 & 1 & 27 \\
\hline $\mathrm{T} 4$ & 7 & 2 & 0 & 0 & 9 \\
\hline \multirow[t]{3}{*}{ 計 } & 29 & 4 & 3 & 1 & 37 \\
\hline & \multicolumn{4}{|c|}{ 声門上癌 } & \multirow{2}{*}{ 計 } \\
\hline & N0 & N1 & N2 & N3 & \\
\hline $\mathrm{T} 1$ & & 2 & 1 & 0 & 3 \\
\hline $\mathrm{T} 2$ & & 2 & 2 & 1 & 5 \\
\hline $\mathrm{T} 3$ & 14 & $10^{*}$ & 6 & 2 & 32 \\
\hline $\mathrm{T} 4$ & 2 & 1 & 2 & $2^{*}$ & 7 \\
\hline 計 & 16 & 15 & 11 & 5 & 47 \\
\hline
\end{tabular}

*M1を各 1 例を含む。

\begin{tabular}{c|c|c|c|c|c}
\hline \multirow{2}{*}{} & \multicolumn{3}{|c|}{ 声門下癌 } & \multirow{2}{*}{ 計 } \\
\cline { 2 - 5 } & $\mathrm{N} 0$ & $\mathrm{~N} 1$ & $\mathrm{~N} 2$ & $\mathrm{~N} 3$ & \\
\hline $\mathrm{T} 1$ & & 0 & 0 & 0 & 0 \\
$\mathrm{~T} 2$ & & 0 & 0 & 0 & 0 \\
$\mathrm{~T} 3$ & 1 & 1 & 0 & 0 & 2 \\
$\mathrm{~T} 4$ & 2 & 0 & 0 & 1 & 3 \\
\hline 計 & 3 & 1 & 0 & 1 & 5 \\
\hline
\end{tabular}

初診時に頸部リンパ節転移を認めた41例中 35 例に手術を施行し, 他の 4 例は手術不能, 2 例 は手術拒否例であった。手術施行例35例中，一 次治療で32例に頸部郭清術を施行した（うち 8 例は両側)。他の 3 例中 2 例は, 術前化学療法 $(\mathrm{PEP} ; 30 \mathrm{mg}, \mathrm{MMC} ; 6 \mathrm{mg} \times 5)$ 施行後, 単 純喉摘のみとし, もう 1 例は術前 $40 \mathrm{~Gy}$ 照射後

表 3 病期III, IVにおける初診時の主訴

\begin{tabular}{l|c|c|c}
\hline & $\begin{array}{c}\text { 声 門 } \\
(37 \text { 例 })\end{array}$ & $\begin{array}{c}\text { 声門上 } \\
(47 \text { 例 })\end{array}$ & $\begin{array}{c}\text { 声門下 } \\
(5 \text { 例 })\end{array}$ \\
\hline 嗄 声 & 34 & 28 & 5 \\
咽頭痛 & 4 & 8 & 0 \\
呼吸困難 & 1 & 3 & 1 \\
異常感 & 2 & 4 & 0 \\
咳 嗽 & 0 & 5 & 0 \\
嚥下困難 & 0 & 2 & 1 \\
頸部腫瘤 & 1 & 7 & 0 \\
\hline
\end{tabular}

(重複あり)

表 4 病期 III, IV に㧍ける症状出現から受診までの期間

\begin{tabular}{c|c|c|c}
\hline \multirow{2}{*}{ 病 期 } & \multicolumn{3}{|c}{ 部 位 } \\
\cline { 2 - 4 } & $\begin{array}{r}\text { 声 門 } \\
n=37\end{array}$ & $\begin{array}{c}\text { 声門上 } \\
n=47\end{array}$ & $\begin{array}{c}\text { 声門下 } \\
n=5\end{array}$ \\
\hline $\begin{array}{c}\text { III, IV 期 } \\
n=89\end{array}$ & $0.5 \sim 36(8.9)$ & $1 \sim 60(6.8)$ & $5 \sim 221(50.0)$ \\
\hline \multicolumn{3}{|c}{ 数值は月数, ( ) は平均 }
\end{tabular}

表 5 病期 III, IVに扔ける根治治療内容

-手術のみ 12例

-手術と放射線併用 39

-手術と化学療法の併用 16

- 三者併用

・放射線のみ

8

4

79 
単純喉摘のみであった。頸部郭清術を施行した 32例中 6 例 $(18.8 \%)$ に頸部リンパ節に再発を 認めた。術前に化学療法を施行し喉頭摘出のみ とした 2 例および単純喉摘のみとした 1 例にも 頸部リンパ節に再発を認めた。

\section{4. 治療成績}

病期別の 5 年累積生存率 (以下, 5 生率) は, III期 $61.9 \%$, IV期 $51.3 \%$ であり，I，II期を含 めた全体では71.3\%であった（図 2)。

表 6 病期III，IVにおける手術術式

\begin{tabular}{c|c}
\hline \multicolumn{1}{c|}{ 術 式 } & 例 数 \\
\hline 全摘術(+RND) & $64(45)$ \\
垂直半側切除術(+RND) & $5(4)$ \\
水平部分切除術 (+RND) & $3(2)$ \\
RNDのみ & 3 \\
\hline 計 & 75 \\
\hline
\end{tabular}

RND : radical neak dissection

はRND併施数

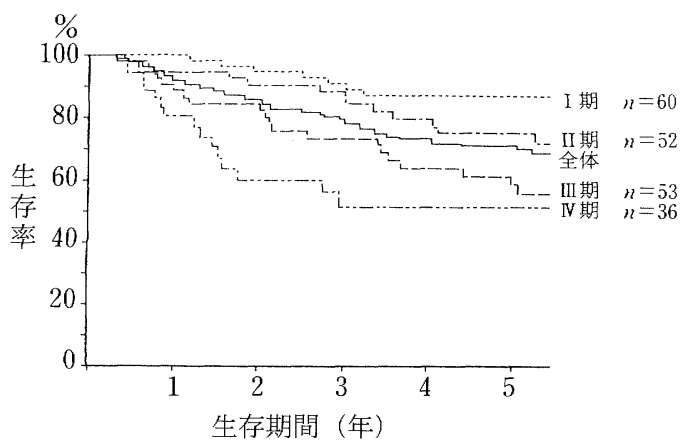

図 2 病期別生存率 (Kaplan-Meier 法)

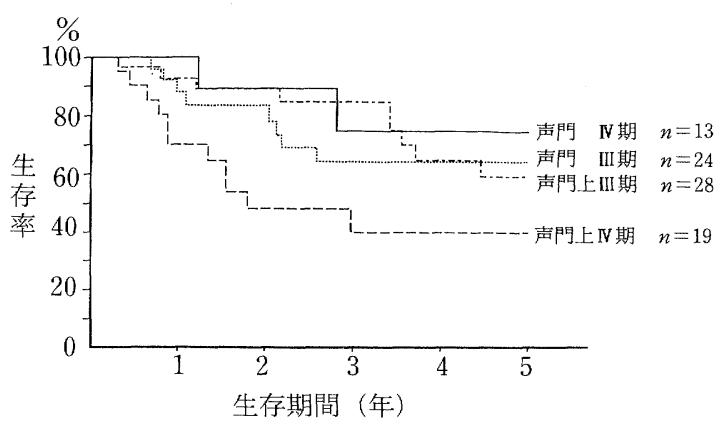

図 3 病期III, IV の部位別生存率（Kaplan-Meier 法)
III，IV期の各部門別 5 生率をみると，声門III 期が $63.8 \%$ ，声門IV期が $74.4 \%$ ，声門上III期が $61.3 \%$ ，声門上IV期が $40.0 \%$ であり，声門上癌 の中でも，特に声門上IV期癌が予後不良であっ た(図 3 )。また, 声門下癌 5 例の 5 生率は 40.1 \%であった。

扁平上皮癌の病理組織学分化度を高分化型， 中分化型, 低分化型の 3 型に分けると ${ }^{5)}$, III, IV 期に打ける内訳は，高分化型38例 (42.7\%)，中 分化型31例 $(34.8 \%)$ ，低分化型20例 $(22.5 \%)$ であった。また抢のおのの 5 生率は高分化型 $69.4 \%$ ，中分化型 $60.6 \%$ ，低分化型 $33.1 \%$ と， 明らかに低分化型の成績が悪かった $(P<0.05$, 図 4 )。

初診時に頸部リンパ節転移を認めた症例 $\mathrm{N}(+)$ 群41例と, 頸部リンパ節転移のなかっ た症例 N（－）群48例との治療成績を比較する と, $\mathrm{N}(+)$ 群 5 生率は $47.5 \%, \mathrm{~N}($ (一) 群は 66.3 \%であったが, 統計学的に有意な差は認められ なかった（図 5 )。N (一) 群の48例中，21例に

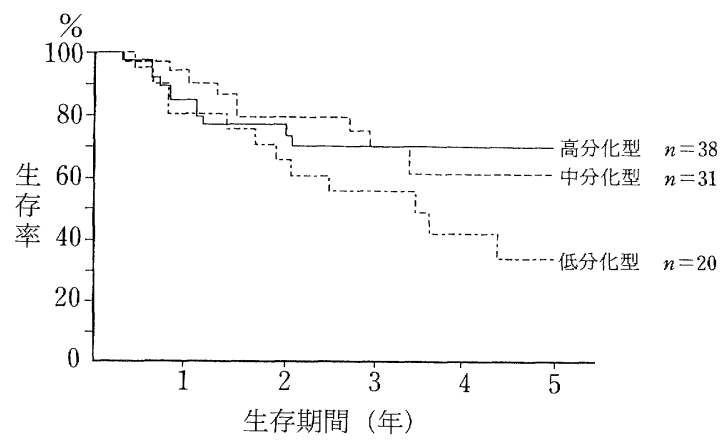

図4 病理組織学的分化度別生存率

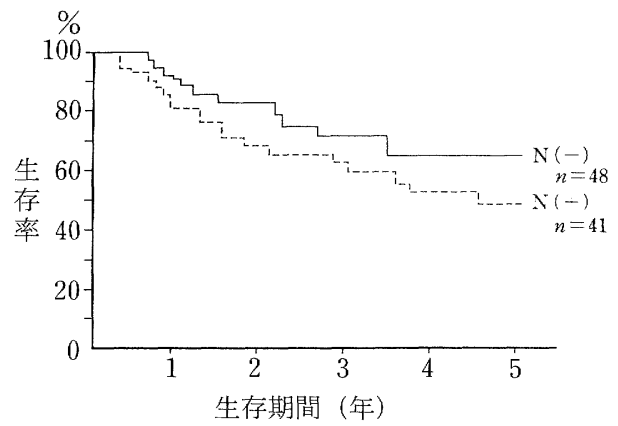

図 5 初診時における $\mathrm{N}(-), \mathrm{N}(+)$ 例の生存率 (Kaplan-Meier 法) 
表 7 臨 床 経 過（声門癌）

\begin{tabular}{|c|c|c|c|c|c|c|c|c|c|c|c|c|}
\hline \multirow{2}{*}{ 病期 } & \multirow{2}{*}{ TNM分類 } & \multirow{2}{*}{\multicolumn{2}{|c|}{ 治療態度 }} & \multirow{2}{*}{ 一次治療 } & \multirow{2}{*}{ 例数 } & \multirow{2}{*}{$\begin{array}{l}\text { 原発巣 } \\
\text { 再 発 }\end{array}$} & \multirow{2}{*}{$\begin{array}{l}\text { 頸部 } \\
\text { 転移 }\end{array}$} & \multirow{2}{*}{$\begin{array}{l}\text { 遠隔 } \\
\text { 転移 }\end{array}$} & \multicolumn{3}{|c|}{ 転 期 } & \\
\hline & & & & & & & & & 生存 & 死亡 & 不明 & \\
\hline \multirow{9}{*}{$\begin{array}{c}\text { III期 } \\
\text { (24例) }\end{array}$} & \multirow{8}{*}{ T3 N0,1 M0 } & \multirow{6}{*}{\multicolumn{2}{|c|}{ 根 治 }} & 放 $\rightarrow$ 手 & 9 & 0 & 3 & 3 & 2 & 6 & 1 & （他病死 1 ） \\
\hline & & & & 化 $\rightarrow$ 手 & 4 & 0 & 0 & 0 & 3 & 1 & 0 & \\
\hline & & & & 放 $\rightarrow$ 化 $\rightarrow$ 手 & 2 & 0 & 0 & 0 & 0 & 2 & 0 & (自殺 1 , 他病死 1 ) \\
\hline & & & & 手＼cjkstart放 & 1 & 0 & 0 & 0 & 0 & 1 & 0 & \\
\hline & & & & 手 術 & 3 & 0 & 0 & 0 & 3 & 0 & 0 & \\
\hline & & & & 放射線 & 2 & 0 & 0 & 0 & 1 & 1 & 0 & （他病死 1 ） \\
\hline & & \multirow{3}{*}{ 姑息 } & $\begin{array}{l}\text { 手術 } \\
\text { 拒否 }\end{array}$ & 放射線 & 1 & 0 & 1 & 1 & 0 & 1 & 0 & \\
\hline & & & \multirow{2}{*}{$\begin{array}{l}\text { 手術 } \\
\text { 不能 }\end{array}$} & 放射線 & 1 & 1 & 0 & 0 & 0 & 1 & 0 & \\
\hline & T2 N1 M0 & & & 化 $\rightarrow$ 放 $\rightarrow$ 化 & 1 & 0 & 0 & 0 & 0 & 1 & 0 & （他病死 1 ) \\
\hline \multirow{8}{*}{$\begin{array}{c}\text { IV 期 } \\
\text { (13例) }\end{array}$} & & \multirow{8}{*}{\multicolumn{2}{|c|}{ 根 治 }} & 放 $\rightarrow$ 手 $\rightarrow$ 放 & 2 & 0 & 0 & 1 & 0 & 2 & 0 & \\
\hline & T3 N2,3 M0 & & & 化 $\rightarrow$ 手 & 1 & 0 & 0 & 0 & 1 & 0 & 0 & \\
\hline & & & & 放 $\rightarrow$ 手 $\rightarrow$ 化 & 1 & 0 & 0 & 0 & 1 & 0 & 0 & \\
\hline & \multirow{5}{*}{ T4 N0,1 M0 } & & & 手＼cjkstart術 & 2 & 0 & 0 & 0 & 2 & 0 & 0 & \\
\hline & & & & 放 $\rightarrow$ 手 & 4 & 0 & 0 & 0 & 4 & 0 & 0 & \\
\hline & & & & 手 $\rightarrow$ 放 & 1 & 0 & 0 & 0 & 1 & 0 & 0 & \\
\hline & & & & 化 $\rightarrow$ 手 $\rightarrow$ 放 & 1 & 0 & 0 & 0 & 1 & 0 & 0 & \\
\hline & & & & 化 $\rightarrow$ 手 $\rightarrow$ 化 & 1 & 0 & 0 & 0 & 1 & 0 & 0 & \\
\hline
\end{tabular}

患側の予防的頸部郭清術を施行した。予防的頸 部郭清群の 5 生率は $69.9 \%$, 非郭清群は $55.7 \%$ であり，有意の差はなかった。

表 5 に示したおのおのの根治治療法別の成績 は，放射線著効を示した 4 例以外の各群におけ る 5 年生存率に有意差は認められなかった。

また，喉頭機能を保存できた 15 例の 5 生率は 68.9\%であった。

\section{5 . 病期III, IVの臨床経過}

1) 声門癌 (表 7)

a) 病期III (24例)

24例中19例に手術を施行した。そのうち16例 に手術を主体とした集学治療を施行し, 残りの 3 例は手術のみであった。手術を施行しなかっ た 5 例のうち 2 例は放射線著効例であり， 1 例 は手術拒否例で放射線のみを施行したが936日
目に死亡。また, 残りの 2 例中 1 例は血液疾患 合併のため手術不能であり，1例は重複癌が術 前に判明したため放射線と化学療法を施行した が740日目に死亡した。

b ) 病期IV (13例)

13例，全例に手術を施行した。そのうち11例 に化学療法, 放射線治療を含めた集学治療を施 行した。残りの 2 例は手術のみであった。

\section{2 ) 声門上癌 (表 8 )}

a ) 病期III（27例）

27例中24例に手術を施行した。そのうち，20 例に手術を主体とした集学治療を施行し, 残り の 4 例は手術のみであった。手術を施行しな かった 3 例のうち 1 例が放射線著効例であり， 残りの 2 例が手術拒否例であった。うち 1 例は 放射線のみで352日目に死亡したが，もう1例は 
表 8 臨 床 経 過（声門上癌）

\begin{tabular}{|c|c|c|c|c|c|c|c|c|c|c|c|c|}
\hline \multirow{2}{*}{ 病期 } & \multirow{2}{*}{ TNM分類 } & \multirow{2}{*}{\multicolumn{2}{|c|}{ 治療態度 }} & \multirow{2}{*}{ 一次治療 } & \multirow{2}{*}{ 例数 } & \multirow{2}{*}{$\begin{array}{l}\text { 原発巣 } \\
\text { 再 発 }\end{array}$} & \multirow{2}{*}{$\begin{array}{l}\text { 頸部 } \\
\text { 転移 }\end{array}$} & \multirow{2}{*}{$\begin{array}{l}\text { 遠隔 } \\
\text { 転移 }\end{array}$} & \multicolumn{3}{|c|}{ 転 期 } & \\
\hline & & & & & & & & & 生存 & 死亡 & 不明 & \\
\hline \multirow{3}{*}{$\begin{array}{c}\text { III期 } \\
\text { (27例) }\end{array}$} & T1,2 N1 M0 & \multirow{2}{*}{\multicolumn{2}{|c|}{ 根 治 }} & $\begin{array}{l}\text { 化 } \rightarrow \text { 手 } \rightarrow \text { 化 } \rightarrow \text { 放 } \\
\text { 手 } \rightarrow \text { 放 } \\
\text { 放 } \rightarrow \text { 手 } \rightarrow \text { 化 }\end{array}$ & $\begin{array}{l}1 \\
2 \\
1\end{array}$ & $\begin{array}{l}0 \\
0 \\
0\end{array}$ & $\begin{array}{l}1 \\
0 \\
1\end{array}$ & $\begin{array}{l}1 \\
0 \\
1\end{array}$ & $\begin{array}{l}0 \\
2 \\
0\end{array}$ & $\begin{array}{l}1 \\
0 \\
1\end{array}$ & $\begin{array}{l}0 \\
0 \\
0\end{array}$ & \\
\hline & T3 N0,1 M0 & & & \begin{tabular}{|l} 
放 $\rightarrow$ 手 \\
手 術 \\
化 $\rightarrow$ 手 $\rightarrow$ 化 \\
手 $\rightarrow$ 放 \\
放 $\rightarrow$ 手 $\rightarrow$ 化 \\
放射線
\end{tabular} & $\begin{array}{r}12 \\
4 \\
2 \\
1 \\
1 \\
1\end{array}$ & $\begin{array}{l}0 \\
0 \\
0 \\
0 \\
0 \\
0\end{array}$ & $\begin{array}{l}1 \\
1 \\
0 \\
0 \\
0 \\
0\end{array}$ & $\begin{array}{l}1 \\
0 \\
1 \\
0 \\
0 \\
0\end{array}$ & $\begin{array}{l}8 \\
3 \\
0 \\
1 \\
1 \\
1\end{array}$ & $\begin{array}{l}4 \\
1 \\
2 \\
0 \\
0 \\
0\end{array}$ & $\begin{array}{l}0 \\
0 \\
0 \\
0 \\
0 \\
0\end{array}$ & （死因不明 1 ） \\
\hline & T3 N0 M0 & 姑息 & $\begin{array}{l}\text { 手術 } \\
\text { 拒否 }\end{array}$ & $\begin{array}{l}\text { 放射線 } \\
\text { 放 } \rightarrow \text { 化 }\end{array}$ & $\begin{array}{l}1 \\
1\end{array}$ & $\begin{array}{l}0 \\
0\end{array}$ & $\begin{array}{l}0 \\
0\end{array}$ & $\begin{array}{l}0 \\
1\end{array}$ & $\begin{array}{l}0 \\
1\end{array}$ & $\begin{array}{l}1 \\
0\end{array}$ & $\begin{array}{l}0 \\
0\end{array}$ & \\
\hline \multirow{4}{*}{$\begin{array}{l}\text { IV期 } \\
\text { (20例) }\end{array}$} & $\mathrm{T} 1,2,3 \mathrm{~N} 2,3 \mathrm{MO}$ & \multirow{2}{*}{\multicolumn{2}{|c|}{ 根 治 }} & $\begin{array}{l}\text { 放 } \rightarrow \text { 手 } \\
\text { 手 } \rightarrow \text { 放 } \\
\text { 化 } \rightarrow \text { 手 } \\
\text { 化 } \rightarrow \text { 手 } \rightarrow \text { 化 } \\
\text { 手 術 }\end{array}$ & $\begin{array}{l}3 \\
1 \\
2 \\
2 \\
1\end{array}$ & $\begin{array}{l}0 \\
0 \\
0 \\
0 \\
0\end{array}$ & $\begin{array}{l}0 \\
0 \\
1 \\
1 \\
0\end{array}$ & $\begin{array}{l}0 \\
1 \\
0 \\
1 \\
0\end{array}$ & $\begin{array}{l}2 \\
0 \\
1 \\
0 \\
1\end{array}$ & $\begin{array}{l}1 \\
1 \\
1 \\
2 \\
0\end{array}$ & $\begin{array}{l}0 \\
0 \\
0 \\
0 \\
0\end{array}$ & (死因不明 1) \\
\hline & T4 N1,2 M0 & & & $\begin{array}{l}\text { 放 } \rightarrow \text { 手 } \\
\text { 化 } \rightarrow \text { 手 } \rightarrow \text { 化 } \\
\text { 化 } \rightarrow \text { 手 } \\
\text { 放 } \rightarrow \text { 化 } \rightarrow \text { 手 }\end{array}$ & $\begin{array}{l}2 \\
1 \\
2 \\
1\end{array}$ & $\begin{array}{l}0 \\
0 \\
0 \\
0\end{array}$ & $\begin{array}{l}0 \\
0 \\
0 \\
0\end{array}$ & $\begin{array}{l}1 \\
0 \\
0 \\
0\end{array}$ & $\begin{array}{l}1 \\
0 \\
1 \\
1\end{array}$ & $\begin{array}{l}1 \\
1 \\
1 \\
0\end{array}$ & $\begin{array}{l}0 \\
0 \\
0 \\
0\end{array}$ & $\begin{array}{l}\text { (他病死 1) } \\
\text { (他病死 } 1 \text { ) }\end{array}$ \\
\hline & $\begin{array}{l}\text { T3 N2 M0 } \\
\text { T2 N3 M0 }\end{array}$ & \multirow[b]{2}{*}{ 姑息 } & $\begin{array}{l}\text { 手術 } \\
\text { 拒否 }\end{array}$ & \begin{tabular}{|l} 
放射線 \\
化 療
\end{tabular} & $\begin{array}{l}1 \\
1\end{array}$ & $\begin{array}{l}1 \\
1\end{array}$ & $\begin{array}{l}0 \\
0\end{array}$ & $\begin{array}{l}0 \\
0\end{array}$ & $\begin{array}{l}0 \\
0\end{array}$ & $\begin{array}{l}1 \\
1\end{array}$ & $\begin{array}{l}0 \\
0\end{array}$ & （治療合併死 1 ） \\
\hline & $\begin{array}{lll}\text { T4 } & \text { N2 } & \text { M0 } \\
\text { T4 N3 } & \text { M1 } \\
\text { T3 N1 } & \text { M1 }\end{array}$ & & $\begin{array}{l}\text { 手術 } \\
\text { 不能 }\end{array}$ & $\begin{array}{l}\text { 放射線 } \\
\text { 放射線 } \\
\text { 放 } \rightarrow \text { 化 }\end{array}$ & $\begin{array}{l}1 \\
1 \\
1\end{array}$ & $\begin{array}{l}0 \\
1 \\
0\end{array}$ & $\begin{array}{l}1 \\
0 \\
0\end{array}$ & $\begin{array}{l}1 \\
0 \\
1\end{array}$ & $\begin{array}{l}0 \\
0 \\
0\end{array}$ & $\begin{array}{l}1 \\
1 \\
1\end{array}$ & $\begin{array}{l}0 \\
0 \\
0\end{array}$ & \\
\hline
\end{tabular}

放射線と化学療法に著効を示し生存中である。 b ) 病期IV (20例)

20例中15例に手術を施行し, うち14例に手術 を主体とした集学治療を施行した。1例に喉頭 全摘, 頸部郭清のみであったが, 900日後に両側 鎖骨上および肺転移を認めた。

手術を施行しなかった 5 例中 3 例が手術不能 例であった。その 3 例中 2 例は肺転移を認めた
ため放射線を主体に治療したが,いずれも107日 目, 277日目に死亡し, 他の 1 例は局所侵襲が強 く, 頸動脈を巻き込んでいたために放射線を根 治量照射したが310日目に死亡した。また，5例 中残りの 2 例は手術拒否例で, 1 例に化学療法 を施行したが 158 日目に死亡, 残りの 1 例に放射 線抒よび温熱治療を施行したが 310 日目に死亡 した。 
表 9 重複癌症例

$\begin{array}{ll}\text { 肺癌 } & 2 \text { 例 } \\ \text { 甲状腺癌 } & 2 \\ \text { 大陽 癌 } & 2 \\ \text { 胃 癌 } & 1 \\ \text { 前立腺癌 } & 1\end{array}$

3 ) 声門下癌

a ) 病期III ( 2 例)

1 例は T3N1M0 で術前40 Gy 照射後, 喉頭全 摘のみ施行し術後照射 $50 \mathrm{~Gy}$ 追加した。その後, 頸部リンパ節に再発したので, サルベージ手術 を施行したが274日目に死亡した。

他の 1 例は, T3N0M0 で85歳と高齢なため喉 頭全摘のみとし，その後経過良好である。

b) 病期IV ( 3 例)

3 例中 2 例に手術を施行した。うち 1 例は, T4N3M0 で喉頭全摘・頸部郭清術後, 化学療法 を施行したが頸部リンパ節転移を制御しきれず 225 日目に死亡した。他の 1 例は80歳高齢男性 で，T4N0M0のため喉頭全摘のみとしたが，頸 部リンパ節領域と肺に再発したため503日目に 死亡した。手術を施行しなかった 1 例は T4N0M0 で放射線著効例であり, 現在まで再発 なく生存している。

\section{6. 再発形式について}

1 次治療後の再発形式についてみると, 遠隔 転移が16例，頸部リンパ節再発が15例，局所再 発が 4 例の順で多い結果であった（初診時遠隔 転移の 2 例は除く)。

1 次治療後, 遠隔転移をきたした16例の原発 部位別の転移頻度をみると，声門上 $8 / 47(17.0$ $\%)$, 声門 $5 / 37$ (13.5\%)，声門下 $3 / 5$ (60.0 \%)であり，全例に肺転移が認められた。

\section{7. 重複癌について}

89 例中 8 例 $(9.0 \%)$ に重複癌が認められた(表 $9)$ 。うち, 癌が 3 力月以内に発見された症例(同 時重複）が 3 例， 3 力月以後に発見された症例 （異時重複）が 5 例であった。

\section{IV. 考 察}

\section{1．年齢分布・性別}

喉頭癌は，頭頸部癌の中では，最も高齢者の
癌である。

病期III・IVにおける年齢分布では70歳代に ピークがあり, 次いで60歳代, 50歳代の順であっ た。一方，当科における病期 I , II を含めた 201 例の年齢分布をみると60歳代にピークがあり， 次いで50歳代, 70歳代の順で, 他の多くの報 告 6,7$)$ と同様であった。このことから喉頭癌の中 でも進行喉頭癌（病期III，IV）患者のなかに高 齢者の占める割合が高く，日本人の平均寿命の 延長に伴い，この傾向はますます増加するもの と考えられる。

男女比についても諸家の報告と同様で，男性 優位の傾向が顕著であった。

\section{2. 発症部位別, 病期別頻度と TNM 分類}

喉頭癌の発生頻度, 発生部位などは地域的, あるいは時代とともに変化してきている。小 野8), 佐藤9)らによれば, 日常生活の西欧化など に伴い声門上部癌に比し声門癌が多くなってき ているといわれている。

病期III, IV期の進行癌は声門癌37例に比し声 門上癌47例と多かった。そこで今回調査した 14 年間の中間点である1982年10月31日より前と後 とで声門癌と声門上癌の発生を比較したところ 声門癌では17例から20例に増加し, 声門上癌で は25例から22例に減少していた。これは, 喉頭 癌の欧米化現象を示唆するものと思われる。ま た，声門上癌のリンパ節転移は $44.3 \% て ゙ あ り ，$ 声門癌の $6.5 \%$ に比し約 7 倍と多く, 予後を左右 する重要な因子の一つと考えられる(表 $2 ， 3$ ， 図 4 )。

\section{3. 主訴および受診までの期間}

喉頭進行癌89例中, 嗄声が主訴であったのは 延べで89例中 67 例 $(75.3 \%)$ と圧倒的に多かっ た。初診時において嗄声を訴えれば声門の異常 を念頭におくが，声門上・声門下癌においては 嗄声以外の諸症状の割合が多いので充分注意し 診断を遅らせてはならない。

症状発現から受診までの期間をみると，III， IV期に扔ける声門, 声門上で有意の差はなかっ た。しかし, 当科括ける声門癌 I, II期の平 均月数をみると 4.6 力月であり, 進行例の方が 2 倍弱の期間を要した。III，IV期での声門上癌の 場合, かなり進行してから症状が出現するので, 生存率を悪くする因子の 1 つと考えられる。一 
方, 声門癌では嗄声が早期に出現するはずであ り，一般社会における嗄声に対するますますの 啓蒙が必要である。

声門下癌III，IV期の症状出現から受診までの 平均期間 50.0 力月という数字は, 受診までに 221 カ月と長期間を要した症例が 1 例あり，また症 例数が少ないため, 他との比較は難しい。

\section{4. 治療成績}

喉頭癌は頭頸部腫瘍の中でも予後の良い腫瘍 といわれているが, 病期III, IVの 5 年生存率だ けをみれば満足すべき成績とはいいがたい。ま た，すでに多くの報告があるように，原発の部 位によりその成績は異なる。

声門癌に比して声門上癌が予後不良である原 因としては, 前記のように声門上癌においては 自覚症状の発現が遅いこと, 頸部転移の頻度が 声門癌の8/37 (21.6\%) に比し, 声門上癌では 31/47 (66.0\%) とかなり高頻度であること, 一 次治療後の遠隔転移16例中, 声門癌 5 例に比し 声門上癌では 8 例と高率であったことが予後に 影響しているといえる。さらに病理組織学的分 化度を見た場合, 佐藤ら ${ }^{9)}$ がいうように最も予 後不良な低分化型が声門癌にはなく, 声門上癌 には認められるといった明確な区別はなかった が, 当科における低分化癌は, 声門型において 4 例であるのに比し声門上癌では13例と多い傾 向にあり, 重大な予後決定因子と考えられた。 すなわち, 病期III, IVにおける声門上癌の占め る割合は $46 / 89(51.7 \%)$ と約半数を占めるため, 声門上癌の予後が進行喉頭癌の予後をかなりの 割合で反映しているともいえる10)。

声門下癌は部位別 5 年生存率が $50.1 \%$ と最も 低く, 声門上癌と同様に一次治療においては, 特に十分な計画をもって対処していかなければ ならない。

治療に当たっては占居部位のみならず, 腫瘍 の進展方向を明らかにすることが特に必要であ る。当科に扔いて術前に T4 の診断が可能で あったのは 7 割弱であり, 吉野ら ${ }^{11)}$ の約 8 割の 診断率と比べて今後さらなる診断率向上が望ま れる。山下ら ${ }^{12)}$ は喉頭ファイバースコピー, X 線, CT 以外に MRI を用いることにより前喉頭 蓋間隙, 喉頭蓋, 甲状軟骨への浸潤や声門下領 域への進展範囲を診断するのに有用であったと

\section{している。}

さらに進展方向を十分考慮にいれた切除が必 要とされる。例えば, 前方進展型では前頸筋群 を剥離せず, 必要により皮膚も合併切除するな ぞの, 各進展方向における拡大全摘術の諸点 ${ }^{11}$ に注意し, 可能なかぎりセーフティマージンを 大きくとることが重要である。

病期別, 発生部位別生存率は, 他施設の成績9) と比較した場合まだ十分満足できる成績とはい えない。今後, さらに早期診断, 放射線治療適 応の厳重な追究, 手術方法の改善, 化学療法の 併用の確立などを通じ, できるだけ高い治療成 績を得られるよう努力すべきと考えている。

\section{5. 頸部リンパ節転移に対する処置}

とくにN2, N3 の症例で局所浸潤が強い場合 は，根本的頸部郭清を徹底しても頸部に再発を みることが少なくない。当科ではリンパ節の被 膜外進展 (extracapsular spread; 以下 ECS) の有無をその後の治療指針の一つにしている。 一般的には, ECS (+) を相対的治癒切除とし て術後照射加化学療法を施行し, ECS (一) を 絶対的治癒切除として経過観察としている ${ }^{13)}$ 。

$N($ ）症例に対する予防的頸部郭清術の有用 性については諸説あり ${ }^{14 \sim 16)}$, その賛否について は意見が分かれるところである。今回の結果で は, 非郭清群の 5 生率 $(55.7 \%$ ) に比へ, 予防 的頸部郭清術の成績 $(69.9 \%)$ が良好であり, 原則的には 1 次治療で完全にコントロールする ことを目指している。患者の全身状態, 腫崵の 進展方向, 年齢等を考慮したうえで, 声門癌 T3N0 では声門上部，下部や反対側への進展が 大きいものには予防的郭清を行い, 声門癌 T4N0 では少なくとも腫瘍側の予防的頸部郭清 術を行っている。また, 声門上癌の T3〜 $4 \mathrm{~N} 0$ の 場合で，腫陽占拠部が正中にある場合，頭蓋内 圧元進の危険を避けるため, 腫瘍占拠部位の大 きい方の内頸静脈を含めた根治的頸部郭清と, 反対側の内頸静脈を温存した機能的頸部郭清を 行っている。ただし, 喉頭蓋から preepiglottic space へ進展する症例で, 声帯, 披裂部, 梨状陥 凹が侵されていない限局した特殊な T4 症例で はその限りではない。

\section{6. 機能保存について}

根治を目的とした治療可能な79例中, 機能保 
存率は $15 / 79(19.0 \%)$ であり,その 5 生率は 68.9 \%であった。これは T1, T2 症例ばかりでなく， 15例中 10 例が T4, T3 症例であることを考慮し てもほぼ満足すべき結果であった。患者自身の 体力や社会復帰後の必要性によるところが大き いが，当科では術後の誤嬹による器下性肺炎を 考慮し, 一般に70歳以上の高齢者には部分切除 は行わず喉頭全摘術を施行している。

Quality of life が叫ばれている今日, 発声機 能を残しておくことは患者にとって重要である が，喉頭全摘術に比し誤嚥と再発の危険が高い という問題がある。また再建部位への再発の場 合，正常解剖と異なるため CT による再発発見 がおくれた症例がある。また，吉野ら ${ }^{17)}$ は部切 をすると barrier となる喉頭の枠組が破壞さ れ，再発の場合は癌の進展形式が乱れ危険であ るので, 部切か全摘か迷う場合は全摘を選択す るとしている。当科においても, 部切を選択す る場合は十分厳選し, 少しでも迷った場合は喉 頭全摘術を選んでいる。

そのためには喉頭摘出後の音声再建外科 ${ }^{18)}$ をより積極的に施行すべきであり，一方では， いまだ speech therapist の数が整っていない日 本においては，こうした面も医師が援助しなけ ればならないと考えている。

\section{7 . 遠隔転移について}

一次治療後, 遠隔転移をきたした16例につい てみると全例に肺転移を認めた。このことより， 術後の経過観察においては特に肺転移の有無に 注意することはいうまでもないが，一度肺転移 をきたした症例の予後は現時点では極めて不良 といわざるを得ない。転移は両側のことが多く， 根治は期待できず対症療法に終ることが多い。 そこで, 肺を含めた遠隔転移による再発を減少 させるためには, 一次治療の中に化学療法を取 り入れた積極的な治療計画が望まれる。

\section{8. 重複癌について}

頭頸部癌, なかでも喉頭癌は重複癌の頻度が 最も高いといわれ和, 平均寿命の延びに伴い, そ の傾向はますます増加するものと思われる。

肺癌は喫煙者に多いといわれているが，さら に喉頭癌と喫煙との関係も知られており ${ }^{20)}$, 喉 頭癌と肺癌は密接にかかわり合うため重複頻度 も高( ${ }^{21)}$ 。
横山ら 22)によると喉頭癌105例中重複癌症例 は, 胃癌の36例, ついで肺癌の13例, 食道癌 10 例，甲状腺癌 7 例などの順であった。

当科に扔いては89例中 8 例 $(9.0 \%)$ が重複癌 であったが，死因不明例を考慮に入れると実際 にはもっと高率と思われる。今後, 高齢化社会 になり, 異時あるいは同時重複癌例数に注意を 払うことが重要で, 初診時, 経過観察期間中に おける他臓器の検索がさらに大切となる。当科 では頭頸部領域癌の初診時から治療開始の期間 においては下咽頭・食道・胃・十二指腸造影, 食道, 胃内視鏡, 胸部単純 $\mathrm{X}$ 線撮影, 気管支鏡 検査をルーチンに施行し, また一次治療後の肺 病変の有無については胸部単純 X 線撮影を施 行し, 少しでも疑いのある場合には，まず無侵 襲な喀痰細胞診を連続 3 日間施行している。

\section{9. 治療方針について}

治療方針を決定する要因は, 大きく 3 つに分 けられる。第 1 は腫瘍側の要因で, 原発病巣の 局在, 進展度, 頸部リンパ節転移の有無, 遠隔 転移の有無など。第 2 亿患者側の要因で年齢, 全身状態, 性格, 社会的経済的状況, 患者個人 の要望など。第 3 に医師の側の要因で, 正確な 診断, 診療能力などが挙げられる ${ }^{23,24)}$ 。これらの 要因を考慮し， 1 人 1 人の患者を診ていくと画 一的にいかないのが実状であった（表 8，10， 11)。

しかし，基本パターンとしては，放射線を 40 Gy 照射した時点で治療効果を検討し， 60〜65 Gy full dose 照射か, 手術 (主に喉頭全摘術) を行うかを決定してきた。すなわち，術前照射 (40 Gy) の段階で腫瘍の縮小傾向の少ないも の, 声帯の運動性回復のないものは, そこで中 止し手術へ移行させた。また, full dose 照射後, 腫瘍の残存している症例も手術へ移行させた。

術前照射は形態と機能を保存する非観血的局 所療法であるから, 喉頭癌治療の第 1 に取り上 げられるべきものと考えられる。当科では根治 治療を目的とした79例中, 術前照射 38 例と根治 照射 4 例をあわせた 42 例 $(53.2 \%)$ に対し，第 1 に放射線治療を施行している。しかし, 時間 的, 経済的, 肉体的に患者の負担が大きい術前 照射であるとか, 術者側に手術術式やその結果 に及ぼす照射の影響が大きい場合は, 手術 ${ }^{25)}$ 
化学療法を選択する場合がある。

佐藤ら ${ }^{9)}$ 沭後照射の有用性について否定的 であるが, Rao ら ${ }^{26)}$, Harry ら ${ }^{27)}$ は局所再発率 や頸部再発率を減少させるとしている。術後照 射は当科に抢いて10例に施行している。統計学 的に有意の差は認められないが，声門下癌に対 して気管傍郭清に不安の残る症例 ${ }^{28)}, \mathrm{N} 0$ 症例 で喉頭外進展している症例には術後照射が必要 かつ有効なものが含まれていると考える。

当科の89例中, 放射線単独治療で喉頭を保存 せしめた症例が 4 例認められたことは興味深 い。しかし，当然のことながら機能保持を重視 するあまり，根治の機会を逸することがあって はならない。今後もさらに放射線科医との密な 連絡が必要とされる。

癌の進行例に対し，医師は患者を救うために 積極的な考えをもつことは必要不可欠なことで ある ${ }^{29)}$ 。患者の側に立ち治療後の quality of life を十分考慮した上に，今後も積極的な combined therapy が必要とされる。この際もつと も重要なことは, 良好な患者一医師関係であり, その上で初めて十分な効果が発揮されるものと 考える。

\section{$\mathrm{V}$.まと め}

1975年から1989年までに治療した進行喉頭癌 新鮮例89例（男女比 9：1）について検討した。

1 ）進行喉頭癌においては声門上癌の占める 割合（47/89，52.8\%）は，声門癌のそれ（37/ 89，41.6\%）に比べて多く，また頸部リンパ節 転移も声門上癌で47例中31例 (66.0\%) と多かっ た。

2 ) 病期別 5 年累積生存率は, 声門癌III期 63.8\%，IV期74.4\%であるが，声門上癌ではIII 期 $60.9 \%$ ，IV期 $40.0 \%$ と，とくに声門上IV期癌 の治療成績が悪かった。

3 ) 初診時, 頸部リンパ節転移を認めた症例 (41例)の 5 生率は $47.5 \%$ で, 転移のない症例 (48 例）は66.3\%であり, 頸部転移例の方が予後不 良の傾向にあった。

4 ）進行喉頭癌は89例中，低分化型扁平上皮 癌は 20 例で, その 5 生率は $33.1 \%$ であり, 高分 化型の 5 生率も $69.4 \%$ に比し, 有意に低かった $(P<0.05)$ 。
以上より，進行喉頭癌，特に声門上，IV期の 低分化型扁平上皮癌に対しては，放射線，化学 療法を含め, 徹底した頸部郭清と拡大切除が必 要で，とくに頻度の高い肺転移に対して全身的 な adjuvant chemotherapy や neoadjuvant chemotherapy の確立が急務である。

\section{文献}

1) 間口四郎, 本村昌一, 酒井 昇・他: $\mathrm{T} 3, \mathrm{~T} 4$ 症 例を中心とした喉頭癌治療成績。耳鼻と臨床, $31: 772-778,1985$.

2）形浦昭克，朝倉光司，森本賢治・他：教室に打 ける喉頭癌の治療成績. 耳展, $28 ： 47-53,1985$.

3 ）市村良介, 白戸 勝, 川堀真一・他：当科に扮 ける喉頭癌の臨床的検討.耳鼻臨床, 補 15 ： 86-94, 1987

4) D'E. Meredith, A.P., Randall, C.J., and Shaw, H.J. : Advanced laryngeal cancer: A management perspective. J. Laryngol. Otol., 101: 1046-1054, 1987.

5 ) Kashima, H.K. : The characteristics of laryngeal cancer correlating with cervical lymph node metastasis. In The Centennial Conference on Laryngeal Cancer (Alberti, P.W., Bryce, D.P., eds) Appleton-Century-Crofts, New York, 847-864, 1974.

6 ) 小野勇: 疫学的にみた喉頭癌の動向. JOHNS, $4: 5-8,1988$.

7 ）甲田嘉彦，吉岡靖弘，太田文彦：当科汸招ける 喉頭癌の統計的観察.耳鼻臨床, 補 $45: 80-87$, 1991.

8 ）小野 勇：早期発見のための喉頭癌の臨床疫 学. 日気食会報, 39:127-132, 1988.

9 ）佐藤武男：喉頭癌一その基礎と臨床, 金原出版, 東京, 1986 .

10）宮原 裕, 鶴田至宏, 馬谷克則・他：喉頭癌患 者死亡例の臨床的検討. 日気食会報，36： 465-472, 1985.

11）吉野邦俊, 佐藤武雄, 馬谷克則 - 他 : 喉頭癌に 抢ける拡大手術 T4 症例についての検討. 頭頸 部腫瘍, $14: 127-131,1987$.

12）山下敏夫, 堀 芳朗, 加藤 勤：喉頭癌の MRI 診断. JOHNS, 9:121-127, 1988.

13) Hirabayashi, H., Koshii, K., Hinohara, T., et al. : Extracapsular spread of squamous cell carcinoma in neck lymph nodes: prognostic factor of laryngeal cancer. Laryngoscope, $101: 502-506,1991$.

14）村上 泰：頭頸部腫瘍の治療。頸部郭清術（平 野 実編), pp.332-349, 医学教育出版社, 東京, 1987.

15）松浦秀博：㑨頭癌診療指針。頸部リンパ節転移 に対する治療 (斉藤成司編)，pp.77-85，医歯薬 出版, 東京, 1981 . 
16）五十嵐文雄，野々村直文，中野雄一：当教室に おける喉頭癌症例の検討. 日耳鼻, $93: 772-778$, 1990.

17）吉野邦俊，佐藤武雄，馬谷克則・他：喉頭癌の 初回治療方針一とくに喉頭全摘・拡大全摘につ いて一。喉頭, 2:78-84, 1990.

18）天津睦郎：喉頭摘出後の音声再建外科. 神戸大 学医学部, 神戸市, 1992.

19）小野 勇：重複癌の基礎と臨床. 頭頸部領域と 他藏器。最新医学，40：1711-1715, 1985 .

20) Hirabayashi, H., Koshii, K., Hinohara, T., et al. : Laryngeal epithelial changes on effects of smoking and drinking. Auris-NasusLarynx, $17: 105-114,1990$.

21）小野良祐，金子昌弘, 池田茂人・他：肺癌と喉 頭癌の合併例の臨床的考察. 日気食会報, 28 : 205-207, 1977.

22）横山道明，生沼尚秋，清水友収：喉頭癌を伴う 重複癌 3 症例。耳鼻臨床, $72 ： 531-540,1979$.

23）菱沼文彦, 加藤 功, 富樫孝一・他：喉頭癌の 治療。耳喉, 49：329-335, 1977 .

24) Lindberg, R.D. : Present day role of radiation therapy in the treatment of head and neck cancer. Cancer of the head and neck, proceedings of an international symposium, Montreux, Switzerland, April 2-4, 1975.

25）中田將風：喉頭癌の診断と予後についての検 討. 広島医学, $37: 85-89,1984$.

26) Rao, V.P., Richard, E., Edwin, J., et al.: Postoperative radiotherapy for persistent tumor at the surgical margin head and neak carcinoma. Laryngoscope, $93: 1337-1340$, 1983

27) Harry, B., Klaas, B., Gordon, S., et al. : The value of post operative radiotherapy as an adjuvant to radical neck dissection. Cancer, $52: 1008-1013,1983$

28) 内田正興, 川端一嘉, 清水佐和道: Stomal recurrence への 対応. JOHNS, 4:465-472, 1988.

29) Burns, L., et al. : Treatment of patients with stage IV cancer. Otolaryngol. Head and Neck Surg., $97: 8-14,1987$. 